\title{
A bacteriological study of hospital beds before and after disinfection with phenolic disinfectant ${ }^{1}$
}

\author{
Denise de Andrade, ${ }^{2}$ Emília L. S. Angerami, ${ }^{2}$ \\ and Carlos Roberto Padovani ${ }^{3}$
}

ABSTRACT In hospitals, one of the ways to control microbial contamination is by disinfecting the furniture used by patients. This study's main objective was to evaluate the microbiological condition of hospital mattresses before and after such disinfection, in order to identify bacteria that are epidemiologically important in nosocomial infection, such as Staphylococcus aureus and Pseudomonas aeruginosa. RODAC plates with two different culture media were used to collect specimens. Patient beds were selected according to previously established criteria, and surface areas on the mattresses were chosen at random. From the total of 1040 plate cultures from 52 mattresses, positive results were obtained from 500 of them (48.1\%), 263 before disinfection and 237 after disinfection. Considering the selectivity of the culture media, the positivity rate was high. There were high prevalences of $\mathrm{S}$. aureus both before and after mattress disinfection. The study results suggest that the usual disinfection procedures, instead of diminishing the number of microbes, merely displace them from one part of the mattress to another, and the number of microorganisms remains the same.

Within the hospital environment, inanimate objects can provide oppor-

\footnotetext{
1 Adapted from: Angelo, D de AD. A manutenção de um ambiente hospitalar biologicamente seguro: avaliação microbiológica dos leitos de um hospital geral antes e depois de sua limpeza terminal. [Maintaining a biologically safe hospital environment: microbiological evaluation of the hospital beds in a general hospital before and after terminal disinfection] [doctoral thesis]. Ribeirão Preto, São Paulo, Brasil: Escola de Enfermagem de Ribeirão Preto da Universidade de São Paulo; 1998.

2 Departamento de Enfermagem Geral e Especializada da Escola de Enfermagem de Ribeirão Preto da Universidade de São Paulo, Ribeirão Preto, São Paulo, Brasil. Send correspondence to: Denise de Andrade, Department of General and Specialized Nursing, Av. Bandeirantes 3900, Campus da USP, 14040-902, Ribeirão Preto, SP, Brasil; e-mail: dandrade@glete.eerp.usp.br

3 Instituto de Biociências do Campus da Universidade Estadual Paulista de Botucatu, Botucatu, São Paulo, Brasil.
}

tunities for contact with and transmission of microorganisms. Hospital disinfection can help in breaking the epidemiological chain of infection. However, many in the scientific medical community consider the inanimate environment to be of less importance in the incidence of hospital infections, and some professionals have confused "less important" with "irrelevant." Nevertheless, the inanimate environment plays a less important role only after basic environmental pollution control measures are established, that is, when minimal cleanliness and disinfection standards are followed (1).

It has long been recognized that there is an urgent need to carry out studies that can help improve the quality of care, as well as lower the rate of nosocomial infections and the costs of hospitalization. However, the fight against nosocomial infections is a complex problem that produces many disputes and disagreements.

The nursing profession has tried to direct its activities toward diminishing the possible risks that trigger hospital infections. One of the activities that nurses perform daily to keep the hospital environment biologically safe is the disinfection of patient "units." The patient unit has been defined as the aggregate spaces and pieces of furniture for use by each patient. While its components vary from one hospital to another, the unit is basically made up 
of a bed, mattress, chair, step stool, bell, and night table with items for personal use (2-4).

The traditional nursing literature recognizes two types of unit disinfection, regular and terminal. Regular disinfection refers to the disinfection performed daily on some parts of the unit and on personal objects after their use. In contrast to this, terminal disinfection of a unit involves all of the unit elements and is done when the patient vacates his bed after he is discharged from the hospital, dies, is transferred, or completes isolation treatment. This type of disinfection is also recommended when a patient has occupied a bed for a long period of time.

In general, both types of disinfection are meant to remove dirt and to impede the spread of microorganisms that colonize the horizontal surfaces of furniture. These microorganisms include Staphylococcus aureus, Clostridium difficile, Pseudomonas spp., Proteus spp., Serratia marcescens, and Candida spp. (5).

When disinfecting the patient unit, the use of chemical products with efficacious germicidal action has been recommended to remove and destroy surface microorganisms. Due to the use of germicidal substances, the terminology related to "cleaning" the patient unit has been changed to "disinfecting," as evidenced in the literature (6-8).

In Brazil, the disinfection products for hospital use must contain phenolic active ingredients, or organic or inorganic compounds that release active chlorine, or ammonia or alcohol quaternaries, or other ingredients complying with current legislation $(1,7,9)$.

The hospital environment offers excellent conditions for the propagation of microorganisms, in spite of disinfectants, antibiotics, and chemotherapeutics. In addition, with their immune systems weakened by illness, surgery, or accidents, patients generally make good hosts for microorganisms.

Further evidence of the need to maintain a biologically safe hospital environment comes from the work by Angelo et al. (10). It showed that in 23 hospitals in the interior of the state of São Paulo, disinfection activities were characterized by a lack of investment in technology, a variety of procedures, and inadequate attention to the scientific principles considered standard in the literature.

Despite the diversity of pathogens involved in hospital infections, a great number of medical studies center on S. aureus and Pseudomonas aeruginosa, which both play important roles in the incidence of hospital infections during all times of the year. These two microorganisms appear as contagious agents harbored by health professionals and by hospital and medical articles, equipment, and other inanimate objects.

The possibilities of a person acquiring an infection depend on various factors. Specifically in relation to the infective dose of $S$. aureus, Marples (11) showed that an inoculation of more than $10^{6}$ colony-forming units (CFUs) can produce pus in healthy skin and that the same is possible with a much lower dose $\left(10^{2}\right.$ CFUs) in traumatized or occluded skin. In the body, $S$. aureus is harbored mainly in the anterior region of the nasal cavities; however, it can also colonize skin lesions (surgical, burns, eczemas, decubitus ulcers, and others), the perineum, and the rectum.

Hands have always been considered an important body area from which to obtain samples of $S$. aureus and other microorganisms. In hospitals, hands are recognized as one of the chief carriers of bacteria from an infected patient to another patient or to a caregiver (12-14).

It is generally considered improbable that the microorganisms present in patient secretions, blood, or other exudates would contaminate the surrounding air, as the microorganisms are restricted to the surfaces where they are deposited. We believe that, of all hospital surfaces, mattresses have the greatest possibility of holding organic matter and microorganisms. Nevertheless, a study by Mendonça (15) indicated that the patient contaminates his immediate environment. In a bacteriological analysis the same phage type was found on patient bed linens and on other patient-unit com- ponents at various distances. The nearer to the patient, the greater was the concentration of microorganisms.

Given that positive relationship of distance and concentration of microorganisms, we believe that the mattress is the element within the patient unit that can harbor the greatest concentration of pathogenic agents. The mattress is the unit element with which the patient has the most contact, especially taking into account that the bed linens are changed daily. In addition, the mattress serves as a depository for organic and inorganic impurities.

Following this line of thinking, we formulated a comparative study on the microbiological condition of hospital mattresses before and after terminal disinfection of the patient unit, with a view toward improving terminaldisinfection procedures. Because of the diversity of microorganisms that can be isolated from hospital mattresses, we decided to focus our attention on S. aureus and P. aeruginosa. Our study had two specific objectives: 1) to measure contamination of mattresses by $S$. aureus and $P$. aeruginosa before and after terminal disinfection of the patient unit and 2) to evaluate the effectiveness of the disinfection procedure in terms of changes in microbial density.

\section{MATERIALS AND METHODS}

The present study was carried out in 1998 in a general public teaching and research hospital in a city located in the interior of the state of São Paulo, Brazil. In light of our interest in evaluating the microbiological conditions of mattresses in that hospital before and after terminal disinfection of the patient unit, we chose a random sample of hospital service areas. Nursing staff members do the disinfection in those areas, following procedures recommended in the literature $(3,4,8)$. Terminal cleaning is structured according to basic principles of disinfection. In short, it is a manual procedure, with actions that are mechanical (friction) and chemical (disinfectant solution and phenol detergent). The phenol 
used is a combination of two phenols (paratertiary butyl phenol and orthobenzil parachlorophenol), which was applied following manufacturer's recommendations for its effective antimicrobial action, including preparation of the solution, concentration, and length of exposure.

Of the 258 active beds in the service units investigated, we took samples from 52 mattresses, or approximately $20 \%$ of the total. We collected samples from each mattress before and after terminal disinfection of the patient unit. We waited approximately 60 minutes before collecting the afterdisinfection samples since phenol has residual effects that are an important factor in reducing the microbial load.

The 52 mattresses sampled included two types of foam mattresses, 18 mattresses covered with cotton fabric and 34 covered with plastic.

Specimens from the mattresses were collected on RODAC ${ }^{\mathrm{TM}}$ (Replicate Organism Detection and Counting) plates, which are recommended in many studies for quantification of microbial surface contamination. Each plate has a capacity of 15 to $20 \mathrm{~mL}$, with $16 \mathrm{~mL}$ as the ideal volume (16). The RODAC plates were primed with one of two culture media, either Bacto Chapman Stone medium (" $\mathrm{CH}^{\prime}$ ) or Bacto cetrimide agar medium ("CT") (17).

Bacto Chapman Stone medium is indicated for the isolation and quantification of Staphylococcus colonies. We used it to count the colonies of Staphylococcus and also to verify the presence of $S$. aureus.

Bacto cetrimide agar medium is used to isolate and culture $P$. aeruginosa. That culture medium typically inhibits the growth of Escherichia coli and of $S$. aureus while producing an excellent growth of $P$. aeruginosa, along with a change of color in the medium to greenish blue or greenish yellow, due to the presence of two pigments, pyocyanin (green) and fluorescein (yellow).

Considering the study objectives, materials used for data collection, and the mattress dimensions, we found it necessary to establish a representative sampling approach. Given the total size of the mattress and the dimensions of the RODAC plates, we divided each mattress into 136 quadrants, from which samples were chosen by lot.

Specimens were collected from the side of the mattress with which the patient had had the most contact. We placed the culture plates with their respective media in the places selected by lot and pressed the plates lightly against the mattress for one minute. For each of the 52 mattresses, we performed the procedure five times before terminal disinfection and five times after terminal disinfection, with both of the culture media, for a total of 1040 cultures.

In the laboratory, the plates were incubated for 48 hours at $37^{\circ} \mathrm{C}$. All the plates, with their respective culture media, were analyzed for odor, morphology of the colonies, color, size, height, borders, and number of colonies. In order to facilitate and standardize the readings, we established three different levels of macroscopic growth: absent, countable, and uncountable. Plates that showed no macroscopic growth of colonies were categorized as "absent," plates with macroscopic growth of up to 130 colonies were labeled as "countable," and plates showing macroscopic growth of more than 130 colonies were categorized as "uncountable."

The plates with cetrimide culture medium underwent general observations and counts and were also checked regularly for changes of color and odor, since this culture medium turns greenish and acquires a sweetish smell in the presence of $P$. aeruginosa.

The plates with Chapman culture medium were submitted to counts of the total colonies and analysis of the colonies as to their size and appearance. All species of Staphylococcus will develop in that culture medium, but only $S$. aureus produces fermentation of the mannitol that is in that medium, so the colonies have a different appearance. To ascertain that the colonies were $S$. aureus, we tested for coagulase, using the technique recommended by Blair (18) and Bayliss and Hall (19). The most generally accepted explana- tion for the coagulase-test reaction is that $S$. aureus is capable of producing coagulase, an "enzyme-like" protein that activates the prothrombin present in serum, transforming it into thrombin, which in turn acts upon fibrinogen to produce fibrin clots.

For our statistical analysis we applied the Goodman test of confidence intervals for multinomial proportions (20), using a computer program produced by Curi and Moraes (21), to compare, for each of the two types of mattress coverings and two culture media, the proportions of changes in the number of colonies before and after terminal disinfection.

For our analysis, we considered the type of mattress and the culture medium and then generated three classification categories: "worsening" (the number of colonies increased), "holding" (the number of colonies stayed the same), and "improving" (the number of colonies decreased).

Results where the comparisons were statistically significant $(P<0.05)$ were annotated in capital letters next to the observed values. Two proportions with at least one letter in common indicate that there was no significant difference in regard to changes in the number of colonies after terminal disinfection.

\section{RESULTS}

\section{Frequency of positive and negative cultures according to culture media before and after terminal disinfection of mattresses}

Out of the total of 1040 plates used to collect specimens from the 52 mattresses, 500 of the plates $(48.1 \%)$ were positive, that is, produced the growth of colonies (Table 1). Of these 500 positive cultures, 263 were gathered before disinfection and 237 were gathered after disinfection. These results did not show a significant difference between positive values before and after terminal disinfection.

The 520 plates containing Chapman culture medium showed high positivity results. Of the 260 Chapman plates used before terminal disinfection of 
TABLE 1. Number and percent of positive and negative cultures from 52 beds before and after terminal disinfection of mattresses, for Chapman (CH) and cetrimide (CT) culture media, Brazil, 1998

\begin{tabular}{|c|c|c|c|c|c|c|c|c|}
\hline \multirow[b]{3}{*}{ Culture } & \multicolumn{4}{|c|}{ Before disinfection } & \multicolumn{4}{|c|}{ After disinfection } \\
\hline & \multicolumn{2}{|c|}{$\mathrm{CH}$} & \multicolumn{2}{|c|}{ CT } & \multicolumn{2}{|c|}{$\mathrm{CH}$} & \multicolumn{2}{|c|}{ CT } \\
\hline & No. & $\%$ & No. & $\%$ & No. & $\%$ & No. & $\%$ \\
\hline Positive & 241 & 92.7 & 22 & 8.5 & 210 & 80.8 & 27 & 10.4 \\
\hline Negative & 19 & 7.3 & 238 & 91.5 & 50 & 19.2 & 233 & 89.6 \\
\hline Total & 260 & & 260 & & 260 & & 260 & \\
\hline
\end{tabular}

the mattresses, 241 of them $(92.7 \%)$ had positive cultures. Of the 260 Chapman plates used after terminal disinfection, $210(80.8 \%)$ had positive cultures. Thus, in contrast to the total number of positive cultures obtained before and after disinfection, with the Chapman plates there was a significant reduction $(P<0.0001)$ in positivity from before to after disinfection of the mattresses.

Out of the total of the 451 Chapman plates that had positive cultures, 286 $(63.4 \%)$ showed positive results for S. aureus. Of those 286, 150 were from cultures done before disinfection and 136 were from cultures done after disinfection, a difference that was not statistically significant.

Taken together, the results with the Chapman culture medium give the impression of there only being a better distribution of the microbial load on the mattress after disinfection, instead of a decrease in the number of microbes.

Similarly, the differences found with the cetrimide culture medium be- fore and after disinfection were not significant.

In addition, in the culture-positive plates containing cetrimide, we did not find growth of pigment-producing $P$. aeruginosa either before or after disinfection of the mattresses. It is possible that the colonies that did appear in the cetrimide culture medium were strains of Pseudomonas without pigment or were some other gramnegative bacteria that does not produce changes in the color of this culture medium.

\section{Number of mattresses with absent, countable, and uncountable microorganism colonies before and after terminal disinfection}

The 52 beds were divided into three groupings according to the number of microorganism colonies found before and after terminal disinfection: absent (no macroscopic growth of colonies), countable (macroscopic growth of up to 130 colonies), and uncountable (macroscopic growth of more than 130 colonies). For the 18 fabric mattresses sampled with the Chapman culture medium, $16(88.9 \%)$ had countable colonies before terminal disinfection and $14(77.8 \%)$ had countable colonies after terminal disinfection (Table 2).

Also with the Chapman culture medium, there were similar percentages of the two types of mattresses with countable colonies after terminal disinfection.

The cetrimide agar culture medium produced results that conflicted with those obtained with the Chapman medium. For the 18 fabric mattresses, all $18(100 \%)$ were in the "absent" category before terminal cleaning, and 14 $(77.8 \%)$ were in that grouping after terminal cleaning. For the 34 plastic mattresses, $23(67.6 \%)$ were in the "absent" category before terminal cleaning, and $19(55.9 \%)$ were in that grouping after terminal cleaning.

The results of positivity with the cetrimide medium were considered low. However, there were some troubling variations before and after disinfection. We did not find any "countable" or "uncountable" colony growth with any of the 18 fabric mattresses before disinfection. Nevertheless, after disinfection, 3 of those mattresses $(16.7 \%)$ had countable colonies and 1 of them $(5.6 \%)$ had uncountable colonies of microorganisms. However, this change was not statistically significant. In the case of the 34 plastic mattresses, with disinfection the number of mattresses from which colonies were absent changed from 23 to 19 , the number with countable colonies remained at 10 , and the number with

TABLE 2. Number and percent of mattresses with absent, countable, and uncountable microorganism colonies before and after terminal disinfection, Brazil, 1998

\begin{tabular}{|c|c|c|c|c|c|c|c|c|c|c|c|c|c|}
\hline \multirow{3}{*}{$\begin{array}{c}\text { Type of } \\
\text { mattress }\end{array}$} & \multirow{3}{*}{$\begin{array}{l}\text { Culture } \\
\text { medium }\end{array}$} & \multicolumn{4}{|c|}{ Absent } & \multicolumn{4}{|c|}{ Countable } & \multicolumn{4}{|c|}{ Uncountable } \\
\hline & & \multicolumn{2}{|c|}{ Before } & \multicolumn{2}{|c|}{ After } & \multicolumn{2}{|c|}{ Before } & \multicolumn{2}{|c|}{ After } & \multicolumn{2}{|c|}{ Before } & \multicolumn{2}{|c|}{ After } \\
\hline & & No. & $\%$ & No. & $\%$ & No. & $\%$ & No. & $\%$ & No. & $\%$ & No. & $\%$ \\
\hline Fabric (18) & $\begin{array}{l}\text { Chapman } \\
\text { Cetrimide }\end{array}$ & $\begin{array}{r}0 \\
18\end{array}$ & $\begin{array}{r}0 \\
100\end{array}$ & $\begin{array}{r}2 \\
14\end{array}$ & $\begin{array}{l}11.1 \\
77.8\end{array}$ & $\begin{array}{r}16 \\
0\end{array}$ & $\begin{array}{r}88.9 \\
0\end{array}$ & $\begin{array}{r}14 \\
3\end{array}$ & $\begin{array}{l}77.8 \\
16.7\end{array}$ & $\begin{array}{l}2 \\
0\end{array}$ & $\begin{array}{r}11.1 \\
0\end{array}$ & $\begin{array}{l}2 \\
1\end{array}$ & $\begin{array}{r}11.1 \\
5.6\end{array}$ \\
\hline Plastic (34) & $\begin{array}{l}\text { Chapman } \\
\text { Cetrimide }\end{array}$ & $\begin{array}{r}1 \\
23\end{array}$ & $\begin{array}{r}2.9 \\
67.6\end{array}$ & $\begin{array}{r}2 \\
19\end{array}$ & $\begin{array}{r}5.9 \\
55.9\end{array}$ & $\begin{array}{l}17 \\
10\end{array}$ & $\begin{array}{l}50.0 \\
29.4\end{array}$ & $\begin{array}{l}27 \\
10\end{array}$ & $\begin{array}{l}79.4 \\
29.4\end{array}$ & $\begin{array}{r}16 \\
1\end{array}$ & $\begin{array}{r}47.1 \\
2.9\end{array}$ & $\begin{array}{l}5 \\
5\end{array}$ & $\begin{array}{l}14.7 \\
14.7\end{array}$ \\
\hline
\end{tabular}


TABLE 3. Changes in the status (number and percent) of microorganism colonies with terminal disinfection of the mattresses, Brazil, 1998

\begin{tabular}{|c|c|c|c|c|c|c|c|c|c|c|}
\hline \multirow{3}{*}{$\begin{array}{c}\text { Mattress } \\
\text { cover }\end{array}$} & \multirow{3}{*}{$\begin{array}{l}\text { Culture } \\
\text { medium }\end{array}$} & \multicolumn{9}{|c|}{ Status } \\
\hline & & \multicolumn{3}{|c|}{ Worsening } & \multicolumn{3}{|c|}{ Holding } & \multicolumn{3}{|c|}{ Improving } \\
\hline & & & No. & $\%$ & & o. & $\%$ & No. & $\%$ & \\
\hline \multirow[t]{2}{*}{ Fabric (18) } & Chapman & 1 & 5.6 & $A^{a}$ & 14 & 77.8 & B & 3 & 16.6 & A \\
\hline & Cetrimide & 0 & 0 & $A$ & 14 & 77.8 & C & 4 & 22.2 & B \\
\hline \multirow[t]{2}{*}{ Plastic (34) } & Chapman & 4 & 11.8 & $A$ & 15 & 44.1 & B & 15 & 44.1 & B \\
\hline & Cetrimide & 8 & 23.5 & B & 24 & 70.6 & C & 2 & 5.9 & A \\
\hline
\end{tabular}

${ }^{a}$ Two proportions with at least one letter in common indicate there was no significant difference in regard to changes in the number of colonies after terminal disinfection.

uncountable colonies increased from 1 to 5 .

\section{Frequency of changes in colony status after terminal disinfection of mattresses}

We compared the number of colonies before and after disinfection of the 52 mattresses for the two culture media. We used those data to assess the number and frequency of changes in that status in terms of the three cat- egories mentioned earlier: worsening, holding, and improving (Table 3).

Using Goodman's test we obtained the following results by comparing values for the categories $(P<0.05)$ :

Plastic CT: Holding > Worsening > Improving

Plastic $\mathrm{CH}: \quad$ (Holding = Improving $)>$ Worsening

Fabric CT: Holding > Improving > Worsening

Fabric $\mathrm{CH}$ : Holding > (Improving > Worsening)

\section{REFERENCES}

1. Scarpitta CRM. Limpeza e desinfecção de artigos hospitalares - limpeza e desinfecção de áreas hospitalares. In: Rodrigues EAC et al. Infecções hospitalares - prevenção e controle. São Paulo: Sarvier; 1997. p. 411-421.

2. Fuerst EV, Wolff L, Weitzel MH. Fundamentos de enfermagem - o humanitarismo e as ciências na enfermagem. 5th ed. São Paulo: Interamericana; 1977.

3. Kawamoto EE, Fortes JI. Fundamentos de enfermagem. São Paulo: Editora Pedagógica e Universitária/EPU; 1986.

4. Mussi NM et al. Técnicas fundamentais de enfermagem. São Paulo: Atheneu; 1995.

5. Pannuti CS. A importância do meio ambiente hospitalar. In: Rodrigues EAC et al. Infecções hospitalares - prevenção e controle. São Paulo: Sarvier; 1997. pp. 449-454.

6. Brasil, Ministério da Saúde. Processamento de artigos e superfícies em estabelecimentos de saúde. 2nd ed. Brasília: Coordenação de Controle de Infecções Hospitalares, Ministério da Saúde; 1994

7. Brasil, Ministério da Saúde. Portaria n. 2616. Diário Oficial da União, 199812 Maio.

8. Ferraz AEP et al. Introdução à enfermagem. Ribeirão Preto: Centro Interescolar do Hospital das Clínicas da Faculdade de Medicina de Ribeirão Preto; 1993.

9. Pedrosa TMG, Macedo RM. Desinfecção e esterilização química e líquida. In: Couto RC et al. Infecção hospitalar - epidemiologia e controle. São Paulo: MEDSI; 1997. pp. 203-217.

10. Angelo $\mathrm{D}$ de AD, Angerami ELS, Oliveira Santos BM, Bispo A. Avaliação da limpeza de unidade terminal do paciente em hospitais do interior do estado de São Paulo. In: Anais do Congresso Brasileiro de Controle de Infecção Hospitalar. Rio de Janeiro, Brasil; 1996. p. 111.

11. Marples RR. Local infections - experimental aspects. Journal of the Society of Cosmetic

12. Larson L, McGinley K, Grove G, Lalbot G. Physiologic and microbiologic changes in skin related to frequent hand washing. Infect Control 1986;7(2):59-63.

13. Oliveira Santos BM, Aguilar OM, Takakura MS. Colonização simultânea de Staphylococcus aureus na cavidade nasal e mãos de portadores sãos de um hospital escola. Rev Microbiol 1990;21(4):309-314.

14. Corrêa I. Avaliação do procedimento da lavagem das mãos no plano assistencial à criança portadora de diarréia aguda bacteriana [doctoral thesis]. Campinas, São Paulo, Brasil: Universidade de Campinas; 1995.

15. Mendonça CP. Estudos sobre Staphylococcus aureus (portadores e infecções hospitalares) num hospital geral de Araraquara, S.P., 19641975 ["livre-docência" thesis]. Araraquara, São Paulo, Brasil: Faculdade de Farmácia e Chemists 1976;27:449-457.
It can thus be seen that, in general, a holding status was the most frequent result for both culture media and both types of mattress coverings. In other words, it appears that the disinfection procedures used did not change the microbial load on the mattresses.

\section{CONCLUSIONS}

Our study has brought up important considerations related to the disinfection procedure for hospital mattresses and has led to reflections on the possibilities of contagion, especially if we really want to ensure maximum efficiency in that disinfection procedure.

Recognizing the part that patients, the environment, and contacts play in the epidemiological chain leading to hospital infections, we health professionals urgently need to break the links in that chain of contagion, using the means of prevention and control appropriate to each specific situation. We will thus take a giant step in reducing the spread of microorganisms.
Odontologia de Araraquara, Universidade Estadual Paulista; 1976.

16. Hall LB, Harnett MJ. Measurement of the bacterial contamination on surfaces in hospitals. Public Health Rep 1964;79:1021-1024.

17. Difco Laboratories. Difco manual: dehydrated culture media and reagents for microbiology. 10th ed. Detroit, Michigan: Difco Laboratories; 1984.

18. Blair JE. Laboratory diagnosis of staphylococcal infections. Bull World Health Organ 1958; 18;(3):291-307.

19. Bayliss BG, Hall ER. Plasma coagulation by organism other than Staphylococcus aureus. J Bacteriol 1965; 89(11):101-105.

20. Goodman LA. On simultaneous confidence intervals for multinomial proportions. Technometrics 1965; 7(2): 247-254.

21. Curi PR, Moraes RV. Associação, homogeneidade e contrastes entre proporções em tabelas contendo distribuições multinomiais. Ciência e Cultura 1981;33(5):712-722.

Manuscript received on 1 December 1998. Revised version accepted for publication on 27 August 1999. 
RESUMEN En los hospitales, una de las formas de controlar la contaminación microbiana es la desinfección de los muebles y utensilios utilizados por los pacientes. El principal objetivo del presente estudio consistió en evaluar las condiciones microbiológicas de los colchones de hospital antes y después de la desinfección, a fin de identificar bacterias epidemiológicamente importantes en las infecciones nosocomiales, tales como Staphylococcus aureus y Pseudomonas aeruginosa. Para recolectar las muestras se utilizaron placas RODAC con dos medios de cultivo diferentes. Las camas de los pacientes fueron seleccionadas según criterios establecidos anteriormente y las áreas de la superficie de los colchones fueron elegidas aleatoriamente. De un total de 1040 placas de cultivo procedentes de 52 colchones, $500(48,1 \%)$ proporcionaron resultados positivos: 263 antes de la desinfección y 237 después de ella. Teniendo en cuenta la selectividad de los medios de cultivo, la tasa de positividad fue elevada. La prevalencia de S. aureus fue alta, tanto antes como después de la desinfección de los colchones. Los resultados de este estudio indican que los procedimientos de desinfección habituales, en vez de reducir el número de microbios, lo único que hacen es desplazarlos de una parte del colchón a otra, pero el número de microorganismos se mantiene.

\title{
Congreso Mundial de Bioética
}

$\begin{array}{ll}\text { Fecha: } & 20 \text { a } 24 \text { de junio de } 2000 \\ \text { Lugar: } & \text { Gijón, Asturias, España }\end{array}$

Este Congreso Mundial de Bioética marcará un hito en las reflexiones sobre los aspectos bioéticos de los adelantos científicos y técnicos que se vislumbran para el siglo XXI. Prestigiosos profesionales de todo el mundo se ocuparán, durante las jornadas del Congreso, de examinar a fondo la aplicación de los conocimientos científicos y tecnológicos. Se debatirán diferentes conjuntos temáticos relacionados con la bioética en una serie de mesas redondas, ponencias y comunicaciones.

日 ambicioso programa de este encuentro internacional ha sido elaborado por un comité científico de reconocido prestigio y convocado por la Sociedad Internacional de Bioética (SIBI), fundada en 1987. 日 Principado de Asturias, donde se celebrará el encuentro, ha sido punto de referencia en la protección y el desarrollo de los derechos humanos y de las libertades fundamentales. Fue en él donde tuvo lugar en 1997 la Convención sobre los Derechos Humanos y la Biomedicina.

\author{
Información: \\ Congreso Mundial de Bioética \\ Sociedad Internacional de Bioética (SIBI) \\ Calle Maternidad 2, $3^{\circ}$ \\ 33207 Gjón, España \\ Teléfono: 985-17-60-06 \\ Fax: 985-17-55-07 \\ Correo electrónico: congreso@sibi.org \\ Página Web: www.bioeticasibi.org
}

